\title{
GENETIC DIVERSITY AMONG Calotropis procera (Aiton) WT Aiton GENOTYPES ACCORDING TO SEED PHYSIOLOGICAL QUALITY ${ }^{1}$
}

\author{
ISAIAS VITORINO BATISTA DE ALMEIDA ${ }^{2 *}$, JEAN PIERRE CORDEIRO RAMOS ${ }^{2}$, WELLISON FILGUEIRAS \\ DUTRA $^{2}$, RISELANE DE LUCENA ALCÂNTARA BRUNO ${ }^{3}$, EDNA URSULINO ALVES ${ }^{3}$
}

\begin{abstract}
Characterizing genetic diversity based on evaluations involving germination and seed vigor, is a fundamental stage in starting the development of a cultivation system for Calotropis procera. Thus, this study aimed to estimate genetic diversity among 35 C. procera genotypes based on germination and vigor of seeds stored for 1 year. The genotypes, which originated from areas in Paraíba (Brazil), where they occur naturally, were collected and stored in March 2014. In order to evaluate the physiological potential of the seeds, two experiments were conducted between March and April 2015. The first involved a propagation test conducted in a germination chamber, while the second involved an emergence test in washed sand, performed in polyethylene trays in a screened environment under uncontrolled conditions. In both experiments, an entirely randomized design was used, with four repetitions of 25 seeds per genotype. The characteristics evaluated were germination, average daily germination, daily germination speed, the speed of germination index, the plantlet vigor index, emergence, the speed of emergence index, total length, and total dry mass. The results showed that genetic variability exists among the $C$. procera genotypes for variables involving germination and vigor of seeds stored for 1 year. Also, emergence, total dry plantlet mass, and germination characteristics contribute most to the genetic divergence among $C$. procera genotypes.
\end{abstract}

Keywords: Silk flowers. Germination. Seed vigor. Genetic variability. Multivariate analysis.

\section{DIVERSIDADE GENÉTICA ENTRE GENÓTIPOS DE Calotropis procera (Aiton) WT Aiton EM FUNÇÃO DA QUALIDADE FISIOLÓGICA DAS SEMENTES}

\begin{abstract}
RESUMO - A caracterização da diversidade genética, com base na avaliação da germinação e do vigor de sementes, é uma etapa fundamental para dar inicio ao desenvolvimento do sistema de cultivo de C. procera. Dessa maneira, objetivou-se estimar a divergência genética em genótipos de $C$. procera baseada na germinação e no vigor de sementes armazenadas por doze meses. Foram utilizados 35 genótipos, oriundos de áreas de ocorrência natural na Paraíba, coletados e armazenados em março de 2014. Para a avaliação do potencial fisiológico das sementes, foram realizados dois experimentos entre março e abril de 2015 . O primeiro constou de um ensaio de germinação conduzido em câmara de germinação, enquanto o segundo, de um ensaio de emergência em areia lavada, realizado em bandejas de polietileno no interior de ambiente de telado em condições não controladas. Em ambos os experimentos foi utilizado o delineamento inteiramente casualizado com quatro repetições de 25 sementes por genótipo. As características avaliadas foram germinação, a germinação média diária, a velocidade diária de germinação, o índice de velocidade de germinação, o tempo médio de germinação, o índice de vigor de plântulas, a emergência, o índice de velocidade de emergência, o comprimento total e a fitomassa seca total. Entre os genótipos de C. procera existe variabilidade genética para variáveis de germinação e vigor de sementes armazenadas por um ano. As características de emergência, fitomassa seca total de plântula e germinação são as que mais contribuem para a divergência genética em genótipos de C. procera.
\end{abstract}

Palavras-chave: Flor-de-seda. Germinação. Vigor de sementes. Variabilidade genética. Análise multivariada.

\footnotetext{
${ }^{*}$ Corresponding author

${ }^{1}$ Received for publication in $08 / 11 / 2016$; accepted in $12 / 15 / 2016$.

Paper extracted from the doctoral thesis of the first author.

${ }^{2}$ Center for Agricultural Sciences, Universidade Federal da Paraíba, Areia, PB, Brazil; isaiasvba@gmail.com, jean.jp31@gmail.com, wfilgueiras@gmail.com.

${ }^{3}$ Department of Phytotechny and Environmental Sciences, Universidade Federal da Paraíba, Areia, PB, Brazil; lanebruno.bruno@gmail.com, ursulinoalves@hotmail.com.
} 


\section{INTRODUCTION}

The main challenges for agricultural development in semiarid regions include the production and availability of fodder during the dry season. These are directly associated with partial or total losses of herds in the Northeast and can often be attributed to a lack of knowledge or even disuse of vegetal species with high productive potential that could be used in the dry season (ANDRADE et al., 2010).

Conversely, xerophytic plant cultivation arises as an alternative for guaranteeing the production of fodder in years with low precipitation and providing food during the dry period, whether in the form of hay, silage, or in natura. Among those plants with the potential to be cultivated in xerophytic farming, silk flower (Calotropis procera (Aiton) WT Aiton) has stood out, mainly because it adapts to a wide range of arid and semiarid regions throughout the world, representing an alternative for minimizing the scarcity of animal feed during critical dry periods (MELO et al., 2001; COSTA et al., 2009). The $C$. procera species features rigorous regrowth after cutting, foliar resistance, tolerance to saline soils, is satisfactorily accepted by animals, and is an excellent source of protein for herds (SILVA et al., 2009; ARRUDA et al., 2011). Another attractive characteristic is its ability to provide phytomass throughout the year.

Although numerous studies have determined the fodder potential of $C$. procera (LIMA et al., 2004; ANDRADE et al., 2005; ANDRADE et al., 2008; OLIVEIRA; SOUTO, 2009), Costa et al. (2009) highlighted the need for more studies regarding the way it is produced. In the vegetal species domestication process, information concerning seed physiological potential, particularly germination and plantlet growth evaluations, constitutes an initial stage in developing a cultivation system.

Consequently, $C$. procera seed germination has been well studied, particularly regarding various temperatures (SILVA et al., 2009; OLIVEIRA-BENTO et al., 2013) and substrates (SILVA et al., 2009; OLIVEIRA-BENTO et al., 2013), as well as wastewater use (CARVALHO JÚNIOR et al., 2010), and seed storage conditions (OLIVEIRA-BENTO et al., 2015). However, there is a lack of published information concerning the physiological potential of its seeds after long storage periods, in particular, characterizing germination variability in the species' genotypes. Thus, this study aimed to estimate genetic divergence among $C$. procera genotypes, based on germination and the vigor of seeds stored for 1 year.

\section{MATERIAL AND METHODS}

The fruits from a total of 35 C. procera genotypes were gathered in March 2014 in areas of the State of Paraíba, Brazil, in which the species occurs naturally (Figure 1). The fruits were collected from plants located a minimum distance of $1000 \mathrm{~m}$ from each other, and choosing fruits with complete physiological maturity (i.e. open pods and brown seeds). The seeds were extracted manually, exposed to the sun for 8 hours and then stored in paper bags at ambient temperature for 1 year.

Two experiments were conducted between March and April 2015 to evaluate the seeds' physiological potential. The first was a propagation test conducted in a BOD (biochemical oxygen demand) germination chamber at the Cultivated Plant Ecophysiology Laboratory located at the Três Marias Integrated Research Complex, of Paraíba State University, Campus I, Campina Grande - PB (Brazil). For this, four subsamples of 25 seeds per genotype were spread over two sheets of paper towel $\left(\right.$ Germitest $\left.^{\circledR}\right)$ and covered by another, all previously wet with distilled water ( $2.5 \mathrm{~g} \mathrm{~g}^{-1}$ of paper) and then rolled up, before they were conditioned in plastic bags and randomly allocated in the interior of a germination chamber for 10 days.

The germination counts were performed between the $6^{\text {th }}$ and $10^{\text {th }}$ days after sowing, using the normal plantlet concept described in Rules for Seed Analysis (BRASIL, 2009). On the $10^{\text {th }}$ day before ending the experiment, five normal plantlets per repetition were collected at random, which were used to quantify the length (PL1), and, after oven drying at $65{ }^{\circ} \mathrm{C}$ for 48 hours, the dry mass (DP1) was quantified.

After gathering the germination, growth, and dry mass data, the germination percentage (GP) (BRASIL, 2009), average daily germination (ADG) (SCOTT; JONES; WILLAMS, 1984), daily speed of germination (DSG) (HUNTR; GLASBEY; NAYLOV, 1984), speed of germination index (SGI) (MAGUIRE, 1962), average germination time (AGT) (CARVALHO; CARVALHO, 2009), and plantlet vigor index (PVI) (MAROUFI; FARAHANI; MOAVENI, 2011) were estimated.

For the second experiment, an emergence test in washed sand was performed in polyethylene trays spread over a worktop inside a screened environment under uncontrolled conditions, at the Brazilian Agricultural Research Company (Embrapa Algodão), Campina Grande - PB (Brazil). An entirely randomized experimental design was used, with four repetitions of 25 seeds per genotype. The substrate was wet until reaching $60 \%$ of its total retention capacity and irrigation was carried out daily until reaching moisture levels close to the initial value. 


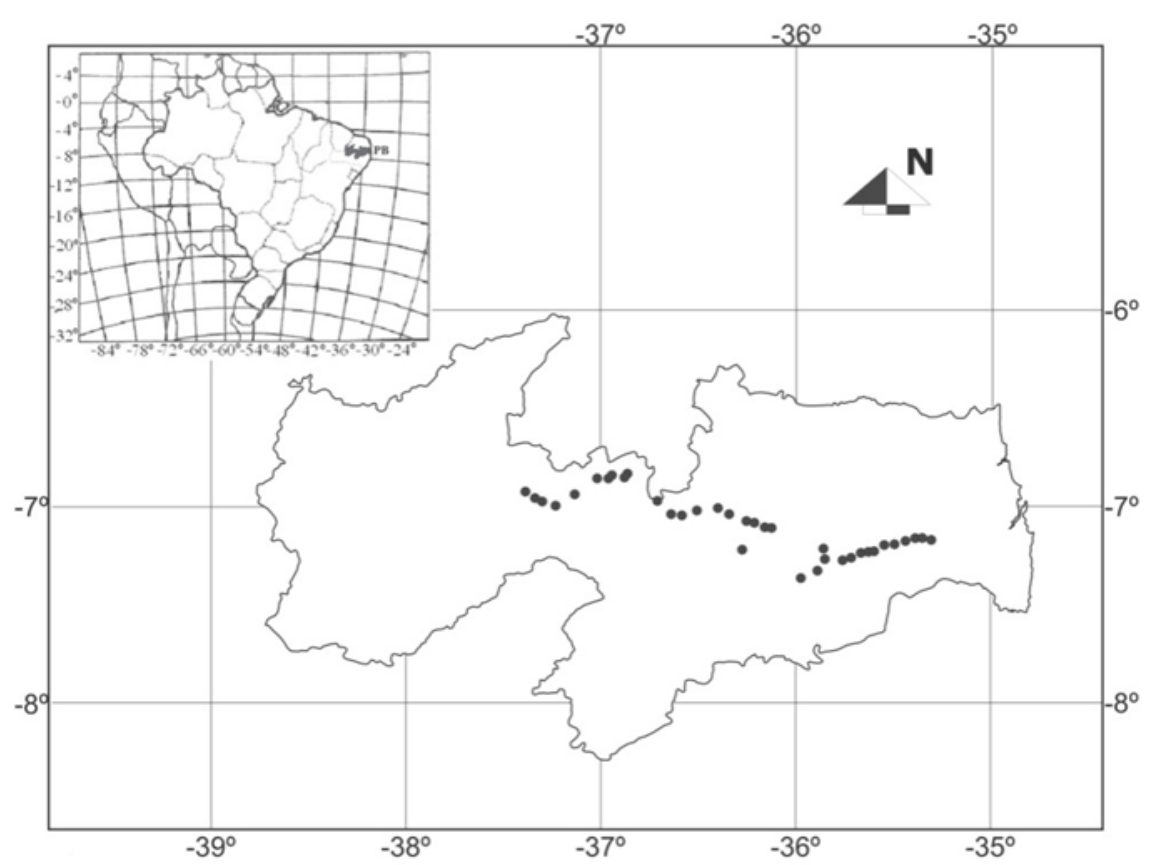

Figure 1. Geographical location of the silk flower (Calotropis procera (Aiton) WT Aiton) fruit collected in the State of Paraíba, Brazil.

The emergence counts were conducted between the $6^{\text {th }}$ and $21^{\text {st }}$ days after sowing. At the end of the experiment, five plantlets per repetition were evaluated for total length (TL2) and total dry mass (TP2). Once this data was gathered, the final emergence percentage (EP) on the $21^{\text {st }}$ day after sowing (BRASIL, 2009), the speed of emergence index (SEI) (MAGUIRE, 1962), and the plantlet vigor index (PVI2) (MAROUFI; FARAHANI; MOAVENI, 2011) were calculated.

The data for the variables were initially analyzed by variance analysis using the $\mathrm{F}$ test, followed by a genetic diversity study using Tocher's optimization method and cluster analysis using the unweighted pair group method with arithmetic mean (UPGMA) hierarchical method, based on the dissimilarity matrix from Mahalanobis $\left(\mathrm{D}^{2}\right)$. Moreover, multivariate and canonical variable analysis was carried out using the GENES software (CRUZ, 2006).

\section{RESULTS AND DISCUSSION}

Table 1 shows the average genotypes values and the general averages for the variables related to the two experiments, which were verified as $4.04 \mathrm{~cm}$
(PL1), 0.0056 g (TP1), 30.23\% (GP), 2.70 (ADG), 0.51 (DSG), 0.12 (SGI), 200.23 hours (AGT), 0.88 (PVI1), $6.74 \mathrm{~cm}$ (PL2), $0.016 \mathrm{~g}$ (TP2), 38\% (EP), 0.08 (SEI), and 1.22 (PVI2). These values are considered normal, although low, considering the studies involved $C$. procera.

In comparison, Silva et al. (2009) and Carvalho Júnior et al. (2010) obtained maximum GPs of 75 and $90 \%$, respectively, while Oliveira-Bento et al. (2013) reported 94\% GP and an AGT of 5.60 days. Thus, a reduction in seed physiological potential was observed in this study, which may be related to the storage time. By evaluating the storage period for $C$. procera seeds, Oliveira-Bento et al. (2015) also verified reductions in GP, EP, and in the SEI after 180 days storage, which decreased from 95,42 , and $4.12 \%$ to a corresponding 80,38 , and $3.94 \%$, respectively.

This information is important as it concerns a species with cultivation potential that is also in the initial phase of domestication. Loss of plantlet vigor is associated with storage time. Furthermore, it is not recommended that $C$. procera is stored at ambient temperature, as the species' seeds are small, easily permeable, and do not remain dormant, which favors a loss in viability. 
I. V. B. ALMEIDA et al.

Table 1. Average values of the variables including germination (GP) (\%), average daily germination (ADG) $\left(\%\right.$ day $\left.^{-1}\right)$, daily speed of germination (DSG), speed of germination index (SGI), average germination time (AGT), plantlet vigor index (PVI1), total length (TL1) (cm), total dry mass (TP1) (g), plantlet emergence (EP) (\%), total length (TL2) (\%), total dry mass (TP2) (g), speed of emergence index (SEI), and plantlet vigor index (PVI2), related to the two experiments with 35 silk flower (Calotropis procera (Aiton) WT Aiton) genotypes.

\begin{tabular}{|c|c|c|c|c|c|c|c|c|c|c|c|c|c|}
\hline \multirow{2}{*}{ Genotypes } & \multicolumn{13}{|c|}{ Variables } \\
\hline & GP & $\mathrm{ADG}$ & DSG & SGI & AGT & PVI1 & TL1 & TP1 & EP & TL2 & TP2 & SEI & PVI2 \\
\hline 1 & 22.00 & 5.50 & 0.188 & 0.100 & 240.00 & 0.229 & 1.23 & 0.0039 & 42.00 & 6.77 & 0.0188 & 0.0920 & 0.65 \\
\hline 2 & 29.00 & 2.23 & 0.462 & 0.114 & 210.60 & 0.531 & 3.61 & 0.0043 & 29.00 & 6.43 & 0.0127 & 0.0711 & 0.89 \\
\hline 3 & 9.00 & 1.38 & 0.792 & 0.106 & 227.50 & 2.781 & 4.73 & 0.0035 & 36.00 & 6.47 & 0.0176 & 0.0805 & 0.73 \\
\hline 4 & 20.00 & 1.73 & 0.595 & 0.114 & 211.07 & 0.726 & 3.24 & 0.0036 & 33.00 & 5.57 & 0.0105 & 0.0738 & 0.70 \\
\hline 5 & 33.00 & 4.13 & 0.255 & 0.107 & 223.51 & 0.163 & 1.25 & 0.0033 & 25.00 & 4.11 & 0.0117 & 0.0813 & 0.80 \\
\hline 6 & 13.00 & 2.00 & 0.583 & 0.109 & 222.00 & 0.560 & 1.59 & 0.0032 & 36.00 & 7.85 & 0.0156 & 0.0853 & 0.88 \\
\hline 7 & 31.00 & 5.08 & 0.215 & 0.103 & 233.25 & 0.329 & 2.46 & 0.0036 & 64.00 & 6.84 & 0.0172 & 0.0811 & 0.43 \\
\hline 8 & 42.00 & 3.10 & 0.365 & 0.127 & 190.48 & 0.691 & 6.69 & 0.0041 & 49.00 & 7.73 & 0.0171 & 0.0848 & 0.64 \\
\hline 9 & 18.00 & 1.23 & 0.844 & 0.126 & 191.25 & 1.372 & 5.02 & 0.0049 & 19.00 & 7.20 & 0.0199 & 0.0862 & 1.58 \\
\hline 10 & 5.00 & 1.00 & 1.000 & 0.101 & 237.00 & 0.850 & 0.98 & 0.0037 & 6.00 & 5.18 & 0.0226 & 0.0702 & 4.39 \\
\hline 11 & 36.00 & 2.90 & 0.373 & 0.110 & 217.84 & 0.470 & 3.86 & 0.0047 & 64.00 & 7.28 & 0.0191 & 0.0910 & 0.46 \\
\hline 12 & 14.00 & 2.63 & 0.509 & 0.107 & 226.29 & 0.693 & 1.29 & 0.0039 & 30.00 & 6.12 & 0.0144 & 0.0734 & 0.84 \\
\hline 13 & 9.00 & 1.08 & 0.938 & 0.113 & 213.00 & 1.944 & 3.60 & 0.0039 & 37.00 & 6.86 & 0.0121 & 0.0773 & 0.76 \\
\hline 14 & 27.00 & 3.21 & 0.334 & 0.111 & 217.63 & 0.739 & 4.38 & 0.0033 & 75.00 & 7.15 & 0.0178 & 0.0872 & 0.38 \\
\hline 15 & 25.00 & 2.23 & 0.509 & 0.136 & 178.71 & 0.766 & 4.55 & 0.0302 & 37.00 & 6.39 & 0.0135 & 0.0829 & 0.70 \\
\hline 16 & 37.00 & 6.08 & 0.215 & 0.110 & 217.40 & 0.094 & 0.85 & 0.0026 & 13.00 & 3.30 & 0.0094 & 0.0723 & 1.42 \\
\hline 17 & 8.00 & 1.63 & 0.667 & 0.121 & 200.00 & 0.713 & 1.28 & 0.0028 & 53.00 & 3.17 & 0.0047 & 0.0633 & 2.58 \\
\hline 18 & 60.00 & 3.75 & 0.271 & 0.133 & 180.74 & 0.398 & 5.88 & 0.0046 & 85.00 & 6.49 & 0.0176 & 0.0771 & 0.49 \\
\hline 19 & 85.00 & 4.25 & 0.237 & 0.130 & 184.04 & 0.335 & 7.05 & 0.0046 & 4.00 & 9.30 & 0.0142 & 0.0928 & 0.44 \\
\hline 20 & 4.00 & 1.00 & 1.000 & 0.149 & 162.00 & 4.625 & 4.63 & 0.0280 & 1.00 & 6.75 & 0.0187 & 0.1046 & 5.39 \\
\hline 21 & 8.00 & 1.75 & 0.708 & 0.110 & 219.00 & 0.479 & 0.90 & 0.0044 & 47.00 & 0.00 & 0.0000 & 0.0000 & 0.00 \\
\hline 22 & 63.00 & 3.90 & 0.272 & 0.138 & 174.39 & 0.378 & 5.93 & 0.0042 & 46.00 & 8.44 & 0.0216 & 0.0818 & 0.73 \\
\hline 23 & 73.00 & 4.57 & 0.240 & 0.138 & 173.85 & 0.378 & 6.77 & 0.0031 & 48.00 & 9.03 & 0.0201 & 0.0849 & 0.79 \\
\hline 24 & 47.00 & 2.79 & 0.367 & 0.119 & 201.34 & 0.347 & 4.00 & 0.0034 & 25.00 & 8.19 & 0.0196 & 0.0832 & 0.68 \\
\hline 25 & 11.00 & 1.63 & 0.667 & 0.137 & 176.50 & 1.725 & 4.49 & 0.0054 & 7.00 & 6.74 & 0.0180 & 0.0916 & 1.11 \\
\hline 26 & 34.00 & 2.69 & 0.421 & 0.145 & 166.38 & 0.894 & 7.53 & 0.0045 & 23.00 & 8.55 & 0.0239 & 0.0885 & 6.06 \\
\hline 27 & 4.00 & 1.00 & 1.000 & 0.111 & 216.00 & 1.175 & 1.18 & 0.0044 & 35.00 & 6.96 & 0.0190 & 0.0756 & 1.25 \\
\hline 28 & 18.00 & 2.13 & 0.531 & 0.151 & 159.25 & 2.011 & 7.51 & 0.0046 & 44.00 & 7.35 & 0.0205 & 0.0978 & 0.87 \\
\hline 29 & 19.00 & 1.65 & 0.625 & 0.115 & 209.40 & 0.723 & 3.36 & 0.0049 & 78.00 & 8.92 & 0.0192 & 0.0925 & 0.85 \\
\hline 30 & 65.00 & 4.15 & 0.244 & 0.147 & 164.13 & 0.471 & 7.64 & 0.0047 & 16.00 & 7.83 & 0.0195 & 0.0821 & 0.41 \\
\hline 31 & 20.00 & 1.30 & 0.796 & 0.129 & 186.60 & 1.051 & 5.20 & 0.0050 & 75.00 & 7.99 & 0.0192 & 0.0807 & 2.17 \\
\hline 32 & 72.00 & 4.25 & 0.237 & 0.122 & 197.11 & 0.345 & 6.08 & 0.0048 & 0.00 & 8.35 & 0.0190 & 0.0815 & 0.45 \\
\hline 33 & 16.00 & 1.75 & 0.583 & 0.121 & 200.00 & 0.611 & 2.29 & 0.0045 & 19.00 & 6.12 & 0.0164 & 0.0851 & 1.29 \\
\hline 34 & 18.00 & 1.27 & 0.804 & 0.126 & 190.60 & 0.844 & 3.55 & 0.0047 & 58.00 & 6.63 & 0.0167 & 0.0790 & 0.46 \\
\hline 35 & 63.00 & 3.58 & 0.286 & 0.127 & 189.23 & 0.434 & 6.68 & 0.0053 & 71.00 & 7.95 & 0.0196 & 0.0741 & 0.45 \\
\hline General averages & 30.23 & 2.70 & 0.518 & 0.122 & 200.23 & 0.882 & 4.04 & 0.0056 & 38.00 & 6.74 & 0.0165 & 0.0802 & 1.22 \\
\hline
\end{tabular}


The cluster analysis for the 35 genotypes using Tocher's method resulted in the formation of four distinct groups (Table 2). The first group included $68.57 \%$ of the genotypes (24), with the average values for GP, PL1, PL2, TP1 and TP2, which are considered important characteristics for crop improvement, lower than the general values. The second group consisted of eight genotypes, which unlike group 1, had higher average values for GP, PL1, PL2, TP1, TP2, and AGT than the general averages, indicating that they are genotypes with the potential for improving $C$. procera. The third group had only two genotypes (15 and 20), which had lower AGT and consequently, higher PVI1 and PVI2, particularly genotype 20 , which qualifies them as individuals with potential for interbreeding. However, new evaluations should be conducted under field conditions to verify their respective productive potentials.

The fourth group comprised only genotype 21 , which due to its value as a genetic resource, should be the target of more research to prove whether or not it can be used in improvement programs. Selecting genotypes with cultivation potential aims to obtain plants with improved characteristics, namely greater germinative potential and seed vigor.

Table 2. Clustering of 35 silk flower (Calotropis procera (Aiton) WT Aiton) genotypes using the Tocher method.

\begin{tabular}{|c|c|}
\hline Groups & Genotypes \\
\hline 1 & $\begin{array}{llllllllllllllllllllllll}9 & 31 & 25 & 2 & 4 & 13 & 29 & 34 & 6 & 33 & 12 & 5 & 1 & 7 & 11 & 24 & 3 & 14 & 10 & 16 & 27 & 17 & 8 & 18\end{array}$ \\
\hline 2 & $\begin{array}{lllllllll}32 & 35 & 22 & 23 & 19 & 30 & 28 & 26\end{array}$ \\
\hline 3 & 1520 \\
\hline 4 & 21 \\
\hline
\end{tabular}

With the aim of observing the dissimilarity between the "inter- and intragroup" individuals in more detail, clustering was done using the UPGMA method. Accordingly, a tree diagram (dendrogram) could be visualized, along with its respective connection points, allowing to holistically estimate the genetic diversity among the genotypes (Figure 2).

The UPGMA method was able to significantly represent the genetic diversity existing among the genotypes, with a satisfactory cophenetic correlation coefficient (CCC) (0.7648). This index indicates the degree of distortion, with regards to the representation of similarity between individuals in a dendrogram, in which values close to the unit represent little distortion. According to Rohlf (1970), a CCC less than 0.7 indicates that mismatching has occurred in the genotype cluster, namely, real genetic diversity is not reliably represented in the two-dimensional array.

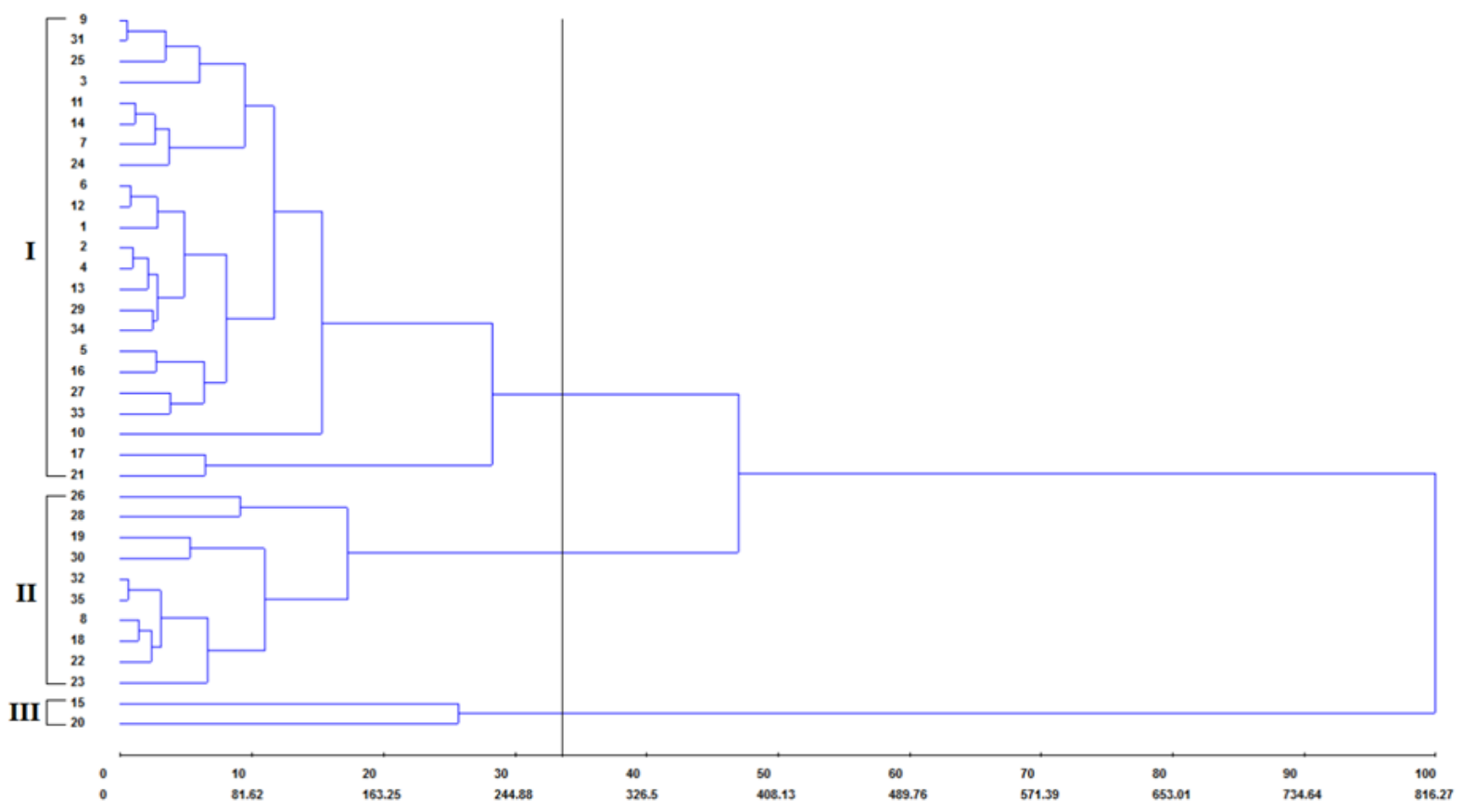

Figure 2. Dendrogram obtained using the UPGMA hierarchical clustering method, based on the dissimilarity matrix $\left(D^{2}\right)$ for 35 silk flower (Calotropis procera (Aiton) WT Aiton) genotypes. The cophenetic correlation coefficient was 0.7648 . Selection criterion based on a dissimilarity index of 274.05 . 
The level of dissimilarity cut-off point of 274.05 using the Mojena criterion (MOJENA, 1977) corresponded to approximately $33 \%$ of total dissimilarity, which enabled three groups to be formed. Unlike the results observed using the Tocher clustering method, genotype 21 remained in group 1 , while genotypes 8 and 18 were included in group 2 . However, group 3 was similar in both cluster methods and contained genotypes 15 and 20, for which the greatest divergence was found in relation to the others, given the high genetic distance observed (Figure 2). Genotype 20 was responsible for high PVI1, PVI2, and low AGT, which shows considerable potential for possible interbreeding, as a way of improving the seed vigor of new generations.

The selection of genotypes with seeds showing improved germinative potential and plantlet growth, particularly after 1-year storage, is indicated for future genetic improvement programs focusing on agricultural use. This conclusion is based on the success of the next steps in the evaluation of species growth, such as the morphophysiological or even molecular descriptors, which mainly depend on initial plant development. These variables are also important in identifying promising genotypes, particularly non-domesticated species, such as silk flower, given that this is an important stage in their domestication. However, despite the importance of germination and emergence variables, in future studies, the same materials need to be evaluated, considering the whole phenological cycle of genotypes.

When genetic diversity is studied using the canonical variables method, the main aim is to identify similar genotypes in two- or three-dimensional scatter plots, which makes it easier to simplify the interpretation of the results (NEGREIROS et al., 2008). In this paper, the analysis using the canonical variables method significantly represented all of the genetic diversity existing between the genotypes in a two-dimensional chart. Thus, the existence of genetic variability between the genotypes evaluated was verified. The first two canonical variables represented $83.04 \%$ of the total variation, with 70.36 and $12.67 \%$ in the first and second canonical variable, respectively. These values are within the estimate proposed by Cruz and Regazzi (1997), in which the minimum variation estimate contained in the first two canonical variables was $80 \%$.

Figure 3 shows the spread of the 35 genotypes, based on the first two canonical variables. In agreement with the UPGMA method, the same three groups were formed, indicating the high potential for these characteristics to represent the genetic diversity among the genotypes studied.

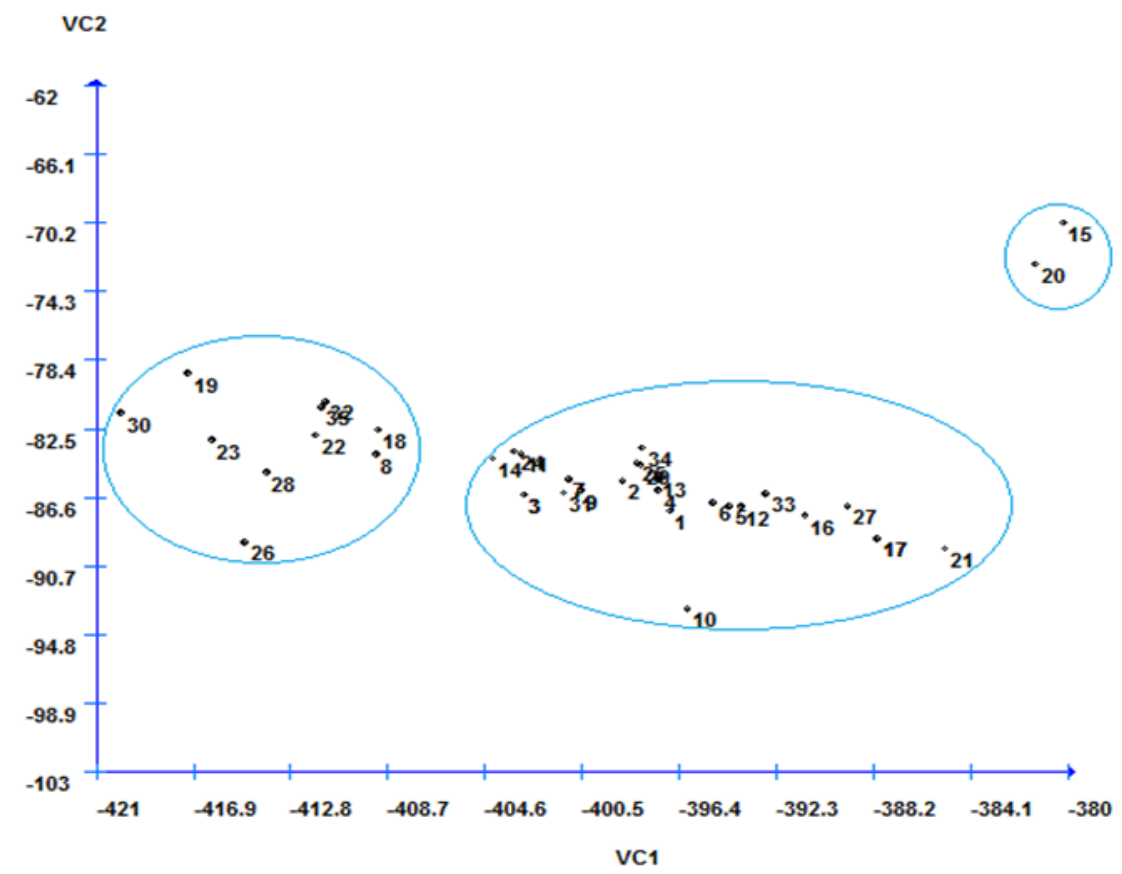

Figure 3. Scatter plot of the 35 silk flower (Calotropis procera (Aiton) WT Aiton) genotypes relative to the first and second canonical variables, established by linearly combining the 13 variables.

Identification of the characteristics that least influenced the differentiation of the genotypes evaluated by the canonical variables was based on isolating the variables that presented the greatest weight in the last eigenvectors. The results allow for variables to be ignored in future studies, reducing research time and costs. In this study, the variables that least influenced the genotype differentiation were $\mathrm{AGT}>\mathrm{SGI}>\mathrm{DSI}>$ PVI2. Therefore, it is proposed that AGT is ignored in future studies.

In quantifying the relative contribution of the characteristics to genetic diversity, the method proposed by Singh (1981) was used. Accordingly, based on the dissimilarity measures obtained using

Rev. Caatinga, Mossoró, v. 30, n. 4, p. 912 - 919, out. - dez., 2017 
the Mahalanobis $\left(\mathrm{D}^{2}\right)$ method, it was possible to obtain the $\mathrm{Sj}$ values (in which $\mathrm{S}$ is the measure of importance relative to the $\mathrm{j}$ variable) for the 13 variables (Table 3 ). It was observed that the EP, TP1, and GP variables contributed most to the differentiation of the 35 genotypes, accounting for $52.92 \%$ of the total distribution. Hence, EP, TP1, and GP can be considered useful variables in future studies to evaluate $C$. procera seed germination, even after 1-year storage. Furthermore, genotypes that produced seeds expressing improved EP, TP1, and GP should be included in future $C$. procera improvement programs, as these are essential characteristics for success in cultivation.

Conversely, the PVI2, ADG, and PL2 variables had the lowest $\mathrm{Sj}$ estimates and, thus, unimportant in evaluating the general divergence between the silk flower genotypes evaluated. Hence, PVI2, ADG, and PL2 should not be used in future studies.

Table 3. Contribution from the 13 variables that differentiated the 35 silk flower (Calotropis procera (Aiton) WT Aiton) genotypes.

\begin{tabular}{crc}
\hline Variable & S.j & Value (\%) \\
\hline EP & 17736.976041 & 25.3633 \\
TP1 & 10216.646979 & 14.6095 \\
GP & 9056.566894 & 12.9506 \\
TL1 & 5702.944049 & 8.155 \\
TP2 & 5676.360937 & 8.117 \\
AGT & 4443.734539 & 6.3544 \\
PVI1 & 4248.167107 & 6.0747 \\
SGI & 3483.099922 & 4.9807 \\
DSG & 2263.124106 & 3.2362 \\
SEI & 2152.320061 & 3.0777 \\
TL2 & 1992.409797 & 2.8491 \\
ADG & 1905.177758 & 2.7243 \\
PVI2 & 1054.214672 & 1.5075 \\
\hline
\end{tabular}

EP - plantlet emergence; TP1 - total dry mass (experiment 1); GP - germination; TL1 - total length; TP2 - total dry mass (experiment 2); AGT - average germination time; PVI1 - plantlet vigor index; SGI - speed of germination index; DSG - daily speed of germination; SEI - speed of emergence index; TL2 - total length (experiment 2); ADG - average daily germination; PVI2 - plantlet vigor index (experiment 2).

\section{CONCLUSIONS}

Genetic variability exists among the $C$. procera genotypes regarding germination and seed vigor variables for seeds stored for 1 year. EP, TP, and GP are the characteristics that contribute most to genetic divergence among $C$. procera genotypes.

\section{ACKNOWLEDGMENTS}

The authors gratefully acknowledge the Federal University of Parnaíba (UFPB) for funding the study, the Coordination for the Improvement of Higher Education Personnel (CAPES) for conceding the grants, and the Cultivated Plant Ecophysiology Laboratory (ECOLAB) and Embrapa Algodão for providing the physical structure for carrying out the study.

\section{REFERENCES}

ANDRADE, A. P. et al. Produção animal no semiárido: o desafio de disponibilizar forragem, em quantidade e com qualidade, na estação seca. Tecnologia \& Ciência Agropecuária, João Pessoa, v. 4, n. 4, p. 1-14, 2010.

ANDRADE, M. V. M. et al. Fenologia da Calotropis procera Ait. R. Br., em função do sistema e da densidade de plantio. Archivos de Zootecnia, Córdoba, v. 54, n. 208, p. 631-634, 2005.

ANDRADE, M. V. M. et al. Produtividade e qualidade da flor-de-seda em diferentes densidades e sistemas de plantio. Revista Brasileira de Zootecnia, Piracicaba, v. 37, n. 1, p. 1-8, 2008.

ARRUDA, A. M. V. et al. Avaliação nutricional do feno de flor-de-seda com aves caipiras. Acta Veterinaria Brasilica, Mossoró, v. 5, n. 3, p. 311-316, 2011.

BRASIL. Ministério da Agricultura, Pecuária e Abastecimento. Regras para análise de sementes. Ministério da Agricultura, Pecuária e Abastecimento. Secretaria de Defesa Agropecuária, Brasília: MAPA/ ACS, 2009. 395 p.

CARVALHO, R. I. N.; CARVALHO, D. B. Germinação de sementes de um ecótipo de paspalum da região de Guarapuava - Pr. Semina: Ciências Agrárias, Londrina, v. 30, Sup. 1, p. 1187-1194, 2009. 
CARVALHO JÚNIOR, S. B. et al. Produção e avaliação bromatológica de espécies forrageiras irrigadas com água salina. Revista Brasileira de Engenharia Agrícola e Ambiental, Campina Grande, v. 14, n. 10, p. 1045-1051, 2010.

COSTA, R. G. et al. Perspectivas de utilização da flor-de-seda (Calotropis procera) na produção animal. Revista Caatinga, Mossoró, v. 22, n. 1, p. 1-9, 2009.

CRUZ, C. D. Programa GENES: análise multivariada e simulação. Viçosa, MG: UFV, 2006. $175 \mathrm{p}$.

CRUZ, C. D.; REGAZZI, A. J. Modelos biométricos aplicados ao melhoramento genético. Viçosa, MG: UFV, 1997. 390 p.

HUNTR, E. A.; GLASBEY, C. A.; NAYLOV, R. E. L. The analysis of data from germination tests. Journal of Agricultural Science, Cambridge, v. 102, n. 1, p. 207-213, 1984.

LIMA, G. F. C. et al. Flor de seda: fonte de feno de qualidade para os sertões. In: Armazenamento de Forragens para Agricultura Familiar. Natal, RN: EMPARN, 2004. 40 p.

MAGUIRE, J. D. Seed of germination aid in selection and evaluation for seedling emergence and vigor. Crop Science, Madison, v. 2, n. 2, p. 176-177, 1962.

MAROUFI, K.; FARAHANI, H.A.; MOAVENI, P. Effects of hydropriming on seedling vigour in spinach (Spinacia oleracea L.). Advances in Environmental Biology, New Delhiv, v. 5, n. 8, p. 2224-2227, 2011.

MELO, M. M. et al. Estudo fitoquímico da Calotropis procera Ait. sua utilização na alimentação de caprinos: efeitos clínicos e bioquímicos séricos. Revista Brasileira de Saúde e Produção Animal, Salvador, v. 2, n. 1, p. 15-20, 2001.

MOJENA R. Hierarchical grouping methods and stopping rules: an evaluation. The Computer Journal, Oxford, v. 20, n. 4, p. 359-363, 1977.

NEGREIROS, J. R. S. et al. Divergência genética entre progênies de maracujazeiro-amarelo com base em características das plântulas. Revista Brasileira de Fruticultura, Jaboticabal, v. 30, n. 1, p. 197-201, 2008.

OLIVEIRA-BENTO, S. R. S. et al. Biometria de frutos e sementes e germinação de Calotropis procera Aiton (Apocynaceae). Bioscience Journal,
Uberlândia, v. 29, n. 5, p. 1194-1205, 2013.

OLIVEIRA-BENTO, S. R. S. et al. Armazenamento de sementes de flor-de-seda [Calotropis procera (Aiton) W.T. Aiton]. Revista Caatinga, Mossoró, v. 28, n. 1, p. 39-47, 2015.

OLIVEIRA, V. M.; SOUTO, J. S. Estimativa da produção de biomassa de Calotropis procera (Ait) R. BR. e avaliação de sua composição química no estado da Paraíba. Revista Verde de Agroecologia e Desenvolvimento Sustentável, Pombal, v. 4, n. 1, p. 141-161, 2009.

ROHLF, F. J. Adaptative hierarchical clustering schemes. Systematic Zoology, Oxford, v. 19, n. 1, p. 58-82, 1970.

SILVA, J. R. et al. Temperatura e substrato na germinação de sementes de flor-de-seda. Revista Caatinga, Mossoró, v. 22, n. 1, p. 175-179, 2009.

SINGH, D. The relative importance of characters affecting genetic divergence. The Indian Journal of Genetics e Plant Breeding, New Delhi, v. 41, n. 2, p. 237-245, 1981.

SCOTT, S. J.; JONES, R. A.; WILLAMS, W. A. Review of data analysis methods for seed germination. Crop Science, Madison, v. 24, n. 6, p. 1192-1199, 1984. 